\title{
Inhibition of Enzymatic and Oxidative Processes by Phenolic Extracts from Spirulina sp. and Nannochloropsis sp.
}

\author{
Priscila Tessmer Scaglioni ${ }^{1 *}$, \\ Larissa Quadros' ${ }^{1}$ Mariane \\ de Paula', Vitor Badiale \\ Furlong ${ }^{2}$, Paulo César Abreu ${ }^{3}$ \\ and Eliana Badiale-Furlong ${ }^{1}$
}

\begin{abstract}
'Laboratory of Food Science and Mycotoxins, School of Chemistry and Food, Federal University of Rio Grande (FURG), Itália Avenue, km 8, Bairro Carreiros, Rio Grande, RS, Brazil ${ }^{2}$ Chemical Engineering Department, Federal University of São Carlos (UFSCAR), Rod. Washington Luiz, km 235, SP 310, São Carlos, SP, Brazil ¿Laboratory of Ecology of Phytoplankton and Marine Microorganisms, Aquaculture and Marine Biotechnology Center, Federal University of Rio Grande, Street of Hotel 2, Querência, Rio Grande, RS, Brazil
\end{abstract}

Received: 31 August 2017 Accepted: 19 April 2018

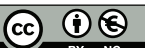

\section{SUMMARY}

This study investigates the capacity of phenolic extracts from microalgae Nannochloropsis sp. and Spirulina sp. to inhibit enzymes and free radical activities, intending to find an innovative way to slow down food damage. HPLC-UV and LC-MS/MS served to determine and confirm, respectively, the phenolic acid profiles in the soluble methanolic (free phenolic) and ethanolic (conjugated phenolic) fractions, and after hydrolysis (bound phenolic fractions). Different procedures measured the antioxidant activity of the extracts to estimate the minimal concentration for the protective effect, stability and versatility of activity. The ability to inhibit the oxidative process (ABTS and DPPH), $a$-amylase and peroxidase activities were estimated as specific inhibition $(\% /(\mathrm{min} \cdot \mu \mathrm{g}))$ for better comparison between the phenolic sources. The phenolic acid mass fractions in the free phenolic extracts from Spirulina sp. and Nannochloropsis sp. were 628 and $641 \mu \mathrm{g} / \mathrm{g}$, respectively. Phenolic extract from Nannochloropsis sp. showed the highest value of ABTS inhibition $(1.3 \% /(\mathrm{min} \cdot \mu \mathrm{g}))$ and highest inhibition of peroxidase activity $(0.4 \% /(\mathrm{min} \cdot \mu \mathrm{g}))$. The extract from Spirulina sp. was a better inhibitor of a-amylase activity $(0.07 \% /(\mathrm{min} \cdot \mu \mathrm{g}))$. Therefore, the phenolic extracts from the edible microalgae may be applied in food industry as natural protector against endogenous and exogenous hydrolytic and oxidative processes.

Key words: amylase, antioxidant activity, peroxidase, phenolic extracts, Nannochloropsis sp., Spirulina sp.

\section{INTRODUCTION}

Microalgae are among the most efficient beings to convert solar energy to organic compounds through metabolism. Their ability to sustain growth and rapid reproduction in adverse media or in land unsuitable for agriculture, such as deserts, and water bodies inadequate for other cultures, like highly salted lakes, makes them more advantageous sources for nutrients and functional compounds than otherwise considered superior vegetables or animals (1).

To withstand these adverse environmental conditions, the microalgal cell metabolism generates compounds to counteract endogenous and exogenous damage. These compounds in the cell or as extracts may also be of benefit for the human diet by providing it with polyunsaturated fatty acids, peptides, chlorophyll, carotenoids, vitamins and phenolic compounds $(2,3)$.

A broad discussion about the applicability of bioactive phenolic compounds is currently underway, with many authors proposing their utilization as dietary supplements against oxidative stress promoted by biotic and abiotic effects (3-5). This utilization finds its rationale in the fact that cells with phenolic compounds in their constitution are more resistant to oxidative damage and fungal contamination, since some phenolic compounds act as hydrolase and oxide reductase inhibitors $(3,6)$. Some phenolic acids have defined biological activities, such as anti-inflammatory and antimicrobial activity (gallic acid) and antifungal effect (caffeic acid) (7). Thus, using these compounds in human food preparations may increase food quality and safety, as well as, possibly, improve the consumer health. 
The biomass from Spirulina sp. and Nannochloropsis sp. microalgae acts as a source of fatty acids, proteins or as an ingredient in food and feed preparations. These species are considered to be more economically advantageous due to their higher production than other microalgae under adverse conditions (8). This suggests that this sort of microalgae may possess compounds that are capable of protecting against physical, chemical and biological hazards. Such compounds can be phenolic acids $(4,6)$; making these microorganisms a potential source of phenolic compounds to explore as natural preservatives in food chain, where the challenge is to avoid the endogenous and exogenous oxidative and hydrolytic processes. Furthermore, it is important to mention that extracting phenolic compounds from the biomass does not hinder other downstream processes that the biomass is subjected to.

However, the ability of these types of biomass to prevent tissue damage has not been extensively studied for the purpose of food preservation. Thus, we assessed the hydrolytic enzymes and free radical inhibition capacity of phenolic acids from Nannochloropsis sp. and Spirulina sp. to find an innovative strategy for food preservation.

\section{MATERIALS AND METHODS}

\section{Characterization of microalgal biomass}

Spirulina sp. biomass is from the Biochemical Engineering Laboratory, Federal University of Rio Grande (FURG), Rio Grande, RS, Brazil, cultivated and dried according to Morais et al. (9). The microalga grew in stirred glass fibre tanks (open raceway pond, volume capacity $10000 \mathrm{~L}$ ) with water from Mangueira lagoon ( $\left(533^{\circ} 30^{\prime} 13^{\prime \prime}\right.$ and W53 $\left.3^{\circ} 08^{\prime} 59^{\prime \prime}\right)$, supplemented with $20 \%$ (by volume) Zarrouk medium (containing in $\mathrm{g} / \mathrm{L}$ : $\mathrm{NaHCO}_{3}$ 16.8, $\mathrm{K}_{2} \mathrm{HPO}_{4}$ 0.50, $\mathrm{NaNO}_{3} 2.5, \mathrm{~K}_{2} \mathrm{SO}_{4} 1.00, \mathrm{NaCl} 1.00$, $\mathrm{MgSO}_{4} \cdot 7 \mathrm{H}_{2} \mathrm{O} 0.20, \mathrm{CaCl}_{2} 0.04, \mathrm{FeSO}_{4} \cdot 7 \mathrm{H}_{2} \mathrm{O} 0.01$ and EDTA 0.08). The microalgal biomass was filtered through a $200-\mu \mathrm{m}$ filter after reaching the concentration of $1 \mathrm{~g} / \mathrm{L}$.

The Nannochloropsis sp. biomass grew in $\mathrm{f} / 2$ medium (culture medium for marine diatoms), salinity $28 \mathrm{PSU}$ (practical salinity units), at $20{ }^{\circ} \mathrm{C}$, light intensity $40 \mu \mathrm{mol} /\left(\mathrm{m}^{2} \cdot \mathrm{s}\right)$ and photoperiod $12 \mathrm{~h}$ light/dark, and dried in the Phytoplankton and Marine Microorganism Laboratory at FURG, Rio Grande, Brazil (1).

The microalgal biomass samples were dried in tray dryers (Q314M; Quimis, São Paulo, Brazil) at $50^{\circ} \mathrm{C}$ for $5 \mathrm{~h}$, ground up to 32 mesh, vacuum packaged (AP450; Tecmac, São Paulo, Brazil) and stored at refrigeration temperature until further analyses.

The chemical characterization of microalgal biomass complied with the AOAC methodology: the moisture content was determined using gravimetry through drying in oven (Q314M; Quimis) at $105^{\circ} \mathrm{C}$ according to method 930.04 (10), lipids were determined by extraction with petroleum ether according to method 954.02 (11), ash was determined by gravimetry, through incineration of the samples in a muffle furnace (Q318M24; Quimis) at $550{ }^{\circ} \mathrm{C}$, as described in method 930.05 (12). Protein levels were determined by the micro-Kjeldahl method 977.02 (13). The crude fibre was determined by acid-base digestion according to method 978.10 (14). The percentages of the other carbohydrates were estimated by difference, considering the sum of protein, lipid, ash, moisture and crude fibre contents.

\section{Extraction of phenolic acids}

Phenolic compounds, soluble in methanol or ethanol, or insoluble (naturally cell wall-bound phenolics) were obtained from the microalgae via the protocols described below. Phenolic compounds soluble in methanol were extracted from $6 \mathrm{~g}$ biomass homogenized with $20 \mathrm{~mL}$ methanol (p.a., Labsynth ${ }^{\circledR}$, São Paulo, Brazil) in an orbital shaker (TE-141; Tecnal, Erechim, Brazil) at $25^{\circ} \mathrm{C}$ and $200 \mathrm{rpm}$ for $60 \mathrm{~min}$. Agitation was interrupted for $15 \mathrm{~min}$ and then restarted, after the addition of $20 \mathrm{~mL}$ methanol, for $90 \mathrm{~min}$. Extracts were centrifuged at $3020 \times \mathrm{g}$ for 10 min (refrigerated centrifuge CT-5000R; Cientec, São Paulo, Brazil) at room temperature, filtered with Whatman filter paper no. 1, evaporated in a rotary evaporator (801-802; Fisatom, São Paulo, Brazil) at $50^{\circ} \mathrm{C}$, diluted in $40 \mathrm{~mL}$ sterile distilled water and clarified with $10 \mathrm{~mL} \mathrm{Ba}(\mathrm{OH})_{2}$ (p.a., Labsynth ${ }^{\circledR}$ ) $0.1 \mathrm{M}$ and $10 \mathrm{~mL}$ $\mathrm{ZnSO}_{4}$ (p.a., Labsynth ${ }^{\circledR}$ ) $5 \%$. Clarified extracts were vacuum filtered (MA 454; Marconi, São Paulo, SP) with sterile membrane (pore size $0.25 \mu \mathrm{m}$; Minisart, Goettingen, Germany) (3).

Phenolic compounds soluble in ethanol were extracted from microalgal biomass with $80 \%$ ethanol (p.a., 1:3 mass per volume; Labsynth ${ }^{\circledR}$ ) in orbital shaker at 300 rpm for $10 \mathrm{~min}$, followed by centrifugation at $3020 \times \mathrm{g}$ and $10^{\circ} \mathrm{C}$ for $15 \mathrm{~min}$ (this procedure was performed twice). The soluble fraction was evaporated and resuspended in distilled water.

The solid residue, from the last step, was used for extraction of bound phenolic compounds by adding $10 \mathrm{~mL}$ hexane (p.a., Labsynth ${ }^{\circledR}$ ), homogenizing in an orbital shaker at 300 rpm for $10 \mathrm{~min}$ and separating by centrifugation at $3020 \times \mathrm{g}$ and $10{ }^{\circ} \mathrm{C}$ for $20 \mathrm{~min}$. The solvent was removed by filtration through Whatman no. 1 filter paper.

The solid phase was hydrolyzed with $60 \mathrm{~mL} 4 \mathrm{M} \mathrm{NaOH}$ (p.a., Labsynth $^{\circledR}$ ) under forced nitrogen atmosphere in orbital shaker at $250 \mathrm{rpm}$ and $25^{\circ} \mathrm{C}$. After $4 \mathrm{~h}, 6 \mathrm{M} \mathrm{HCl}$ (p.a., Labsynth ${ }^{\circledR}$ ) was added to reach $\mathrm{pH}=1$. The suspension was centrifuged at $3020 \times g$ and $10{ }^{\circ} \mathrm{C}$ for $40 \mathrm{~min}$ and then the supernatant was used in a partition with ethyl acetate (p.a., Labsynth ${ }^{\circledR}$ ) (three times in $30 \mathrm{~mL}$ ). The liquid was further separated with Whatman no. 1 filter paper with anhydrous $\mathrm{Na}_{2} \mathrm{SO}_{4}$ P.A. (p.a., Labsynth $^{\circledR}$ ) and evaporated in a rotary evaporator at $60{ }^{\circ} \mathrm{C}$ and resuspended in sterile water (15). Fig. 1 shows the analytical sequence for obtaining the three phenolic extracts from the microalgal biomass.

\section{Quantification of phenolic acids}

The phenolic acids found in the algal extracts (standards by Sigma-Aldrich, Merck KGaA, St. Louis, MO, USA: caffeic, chlorogenic, coumaric, ferulic, gallic, hydroxybenzoic, protocatechuic, syringic and vanillin) were determined by using 


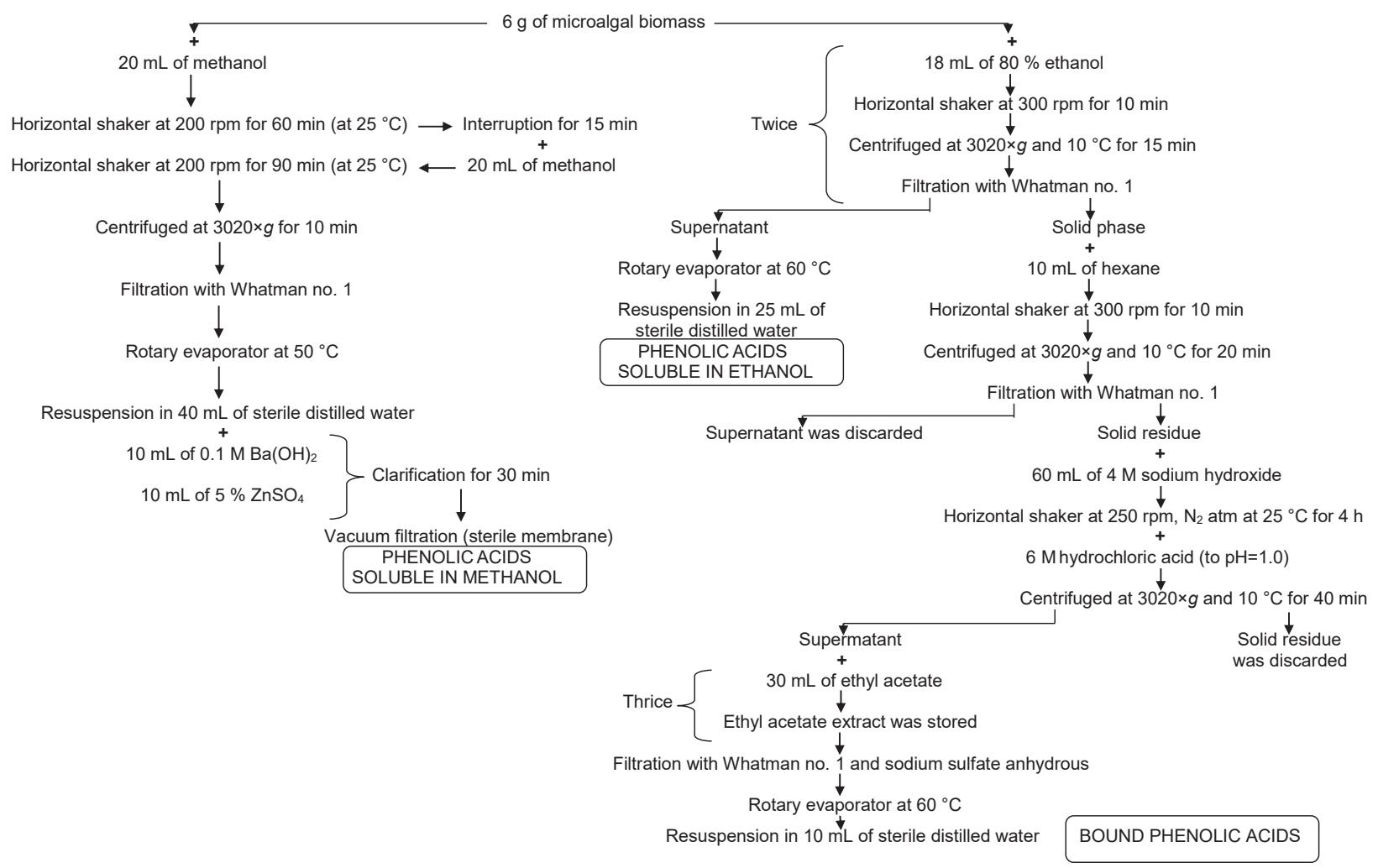

Fig. 1. Extraction methods of microalgal phenolic acids

an aliquot dried under nitrogen flow, resuspended in methanol/water mixture (1:1) and separated by high-performance liquid chromatography (CLASS-M10A; Shimadzu, Tokyo, Japan) coupled to ultraviolet detector, with the use of a C18 reversed-phase column $(4.6 \mathrm{~mm} \times 250 \mathrm{~mm}, 5 \mu \mathrm{m}$; Discovery, Bellefonte, PA, USA). The mobile phase flow rate was $0.7 \mathrm{~mL} /$ min at $35^{\circ} \mathrm{C}$, with an isocratic elution of solvents composed of HPLC grade methanol (J.T. Baker, Phillipsburg, NJ, USA) and water with $1 \%$ acetic acid in the ratio 20:80 (by volume) for 25 min. Phenolic acids in the eluate were measured at $280 \mathrm{~nm}$ up to $15 \mathrm{~min}$ of elution and at $320 \mathrm{~nm}$ up to the final $25 \mathrm{~min}$ (15).

The efficiency of the chromatographic separation was estimated by the retention factor $(k)$ which is equal to the ratio of retention time of every phenolic acid on the column and the retention time of an unretained compound (dead time). The separation factor $(a)$ was estimated between two phenolic acids as the ratio of their retention factors $\left(k_{A} / k_{B}\right)(16)$.

To confirm the results, the artificial extracts were subjected to HPLC analysis in an Alliance 2695 Separations Waters liquid chromatograph (Milford, MA, USA) coupled to a mass detector (LC-ESI-MS/MS) fitted with an autosampler, a membrane degasser and a quaternary pump. Mass spectrometry was performed on a Micromass Quattro Micro ${ }^{\mathrm{TM}}$ API (Waters) with an electrospray ionisation (ESI) interface. Additionally, data were acquired with MassLynx v. 4.1 (17), and a Waters XTerra ${ }^{\circledR}$ MS C 18 column, $3.5 \mu \mathrm{m}, 144 \AA$ ( $50 \mathrm{~mm} \times 3 \mathrm{~mm}$ i.d.) was used. The mobile phase was methanol, ultrapure water with $0.1 \%$ acetic acid (90:10), in an isocratic elution and a flow rate of $0.3 \mathrm{~mL} / \mathrm{min}$. The fragmentation conditions were: source temperature $100{ }^{\circ} \mathrm{C}$, desolvation temperature $400{ }^{\circ} \mathrm{C}$, and desolvation gas flow $\left(\mathrm{N}_{2}\right)$ and cone gas flow 500 and $50 \mathrm{~L} / \mathrm{h}$, respectively. The capillary voltage was $4 \mathrm{kV}$ and the extractor $2 \mathrm{~V}$. Table 1 shows the phenolic compounds and the fragmentation conditions that were studied. The conditions were as determined by Singh et al. (18).

Table 1. Liquid chromatography/electrospray ionization tandem mass spectroscopy (LC-ESI-MS/MS) analysis of phenolic acids

\begin{tabular}{lcccc} 
Phenolic acid & ESI & $\begin{array}{c}\text { Transition }(\mathrm{m} / \mathrm{z}) \\
\text { Precursor ion } \\
\rightarrow \text { Product ion }\end{array}$ & $\begin{array}{c}\text { Cone } \\
\text { voltage/V }\end{array}$ & $\begin{array}{c}\text { Collision } \\
\text { energy/eV }\end{array}$ \\
Gallic & - & $169>125$ & 25 & 16 \\
Protocatechuic & - & $153>109$ & 25 & 16 \\
Chlorogenic & - & $353>191$ & 25 & 16 \\
4-Hydroxybenzoic & - & $137>193$ & 25 & 16 \\
Caffeic & - & $179>135$ & 25 & 16 \\
Syringic & - & $197>182$ & 25 & 16 \\
4-Coumaric & - & $163>119$ & 25 & 16 \\
Ferulic & - & $193>134$ & 25 & 16 \\
\hline
\end{tabular}

Determination of antiradical activity and enzyme inhibition of phenolic extracts

The antiradical activity of the microalgal extracts was estimated by four different methods, with some alterations. In these experiments, only the phenolic extracts extracted with methanol were used, since antifungal tests showed that 
these extracts have the highest potential (results not shown). Solutions with a mixture of the most abundant phenolic acid standards were also formulated with the same ratios found in the natural extract.

Inactivation of the $\mathrm{ABTS}^{+}\left(2,2^{\prime}\right.$-azino-bis(3ethylbenzothiazoline-6-sulphonic acid) radical action

The oxidation of the 1:1 mixture of $7 \mathrm{mM}$ ABTS (Sigma-Aldrich, Merck KGaA) and $2.45 \mathrm{mM}$ potassium persulfate (p.a., Labsynth), which rested for $16 \mathrm{~h}$ at room temperature protected from direct sunlight, formed the radical. Afterwards, the dilution of the solution gave an absorbance of about 0.7 (at $734 \mathrm{~nm}$ ) determined with a spectrophotometer (SP220; Biospectro, São Paulo, Brazil). Different dilutions of microalgal phenolic extracts served to determine the scavenging capacity of the radical cation. $\mathrm{ABTS}^{+}$capture results led to a linear regression of the percentage of inhibition and the concentration of phenolic compounds found in every extract. Then, we calculated the line equations and the respective $I C_{50}$ values, which correspond to the minimum inhibitory concentration required to capture $50 \%$ of the ABTS radical (19).

\section{Scavenging of free DPPH radical}

Decrease of absorbance measured with the spectrophotometer at $515 \mathrm{~nm}$ (20) helped determine the 2,2-diphenyl-1-picrylhydrazyl (DPPH) free radical consumption by the extracts. Both $0.5 \mathrm{~mL}$ water (control) and $0.5 \mathrm{~mL}$ of the extract solution under study were added to the tubes with 3.0 $\mathrm{mL}$ DPPH (Sigma-Aldrich, Merck) solution $\left(5 \cdot 10^{-5} \mathrm{~mol} / \mathrm{L}\right)$. The reactive mixture was kept at room temperature, protected from direct sunlight, and the change from violet to yellow was measured at $0,30,60,90,120,150$ and $180 \mathrm{~min}$ of the reaction. The capacity to scavenge the free radical was expressed as the percentage of oxidation inhibition in every time interval as follows:

$$
\text { Inhibition }=\left(\left(A_{\mathrm{DPPH}}-A_{\mathrm{e}}\right) / A_{\mathrm{DPPH}}\right) \cdot 100
$$

where $A_{\mathrm{DPPH}}$ is the absorbance of the control, and $A_{\mathrm{e}}$ is the absorbance of the extract of the sample.

\section{Inhibition of peroxidase}

The enzyme peroxidase was obtained from pink eye potatoes (Solanum tuberosum) bought in a local market (Walmart Hypermarket, Rio Grande, Brazil). The potatoes were washed, dried, peeled and chopped into $1-\mathrm{cm}^{3}$ cubes. Phosphate buffer (Labsynth) $0.010 \mathrm{~mol} / \mathrm{L}, \mathrm{pH}=5$, in 1:10 (mass per volume) ratio, was combined with the potato and mixed in orbital shaker (TE-141; Tecnal) at 100 rpm and room temperature for $60 \mathrm{~min}$. The mixture was then centrifuged at $4^{\circ} \mathrm{C}$ and $3220 \times \mathrm{g}$ (CT-5000R; Cientec) for $10 \mathrm{~min}$, filtered and diluted to $50 \mathrm{~mL}$ with the same buffer from the last step. Afterwards, $20 \mathrm{~mL}$ of the supernatant were separated, $10 \mathrm{~g}$ ammonium sulfate
(Labsynth) and $20 \mathrm{~mL}$ acetone (p.a., Labsynth) (manually homogenized for $1 \mathrm{~min}$ ) were added to it. The suspension rested for $60 \mathrm{~min}$ and was centrifuged at $3220 \times \mathrm{g}$ and $4{ }^{\circ} \mathrm{C}$ for $20 \mathrm{~min}$. Fractions on the top (acetone) and bottom (salt) were removed so that only the precipitate with the peroxidase remained. It was then resuspended with $20 \mathrm{~mL}$ of phosphate buffer, $5 \mathrm{mmol} / \mathrm{L}, \mathrm{pH}=5.5$, homogenized for $2 \mathrm{~min}$ and filtered (21).

The oxidation reaction of the substrate (guaiacol, from Vetec Química Fina, São Paulo, Brazil) occured with the help of the cofactor $\mathrm{H}_{2} \mathrm{O}_{2}$ (p.a., Labsynth) in a buffered medium and was catalyzed by the addition of peroxidase or inhibited by the addition of phenolic extract. After the addition of components, all reactors were kept in a water bath at $30^{\circ} \mathrm{C}$ for 10 min and the transmittance of the products was determined by a spectrophotometer (SP220; Biospectro) at $470 \mathrm{~nm}$ (22).

$A$ unit of the activity of the enzyme peroxidase was defined as the protein amount that triggers the increase of 0.001 absorbance units per minute. The determination of the specific enzyme activity took into account the amount of protein in the reactive medium $(\mathrm{mg} / \mathrm{mL})$. The protein concentration was estimated by the Lowry et al. (23) method based on the standard curve of bovine serum albumin.

The inhibitory activity of microalgal extracts was expressed as the percentage of inhibition of the darkening reaction compared to the control assay (100\%).

\section{Inhibition of a-amylase activity}

The commercial enzyme a-amylase from Aspergillus oryzae (Fungamyl ${ }^{\oplus} 800$ L, CEE 2006/ 121; Novozymes Latin America, Paraná, Brazil) was used as standard. The enzyme solution activity was determined by the starch degradation rate estimated by the iodometric method (24). A control assay was carried out with water in place of the enzyme extract and another control had every phenolic extract under investigation (natural extracts and synthetic mixtures from both microalgae). In the controls, the enzyme activity was determined without inhibitors. In order to investigate the amylolytic activity, the components of the reactors were homogenized. After 30 min at $\mathrm{pH}=6$ (phosphate-citrate buffer, Labsynth) in water bath at $25^{\circ} \mathrm{C}$, transmittance was measured by a spectrophotometer (SP220; Biospectro) at $620 \mathrm{~nm}$. The inhibition percentage of every inhibitor was estimated as the difference of the enzyme activity without inhibitor (100\%) and the enzyme activity in the presence of the inhibitor.

\section{Statistical analysis}

Analysis of variance (ANOVA) determined the results of the antiradical activity, followed by the Tukey's test with $95 \%$ confidence level, using Statistica v. 12 (25) to verify the influence of different phenolic acids found in the microalgal extracts on the antiradical potential. 


\section{RESULTS AND DISCUSSION}

\section{Chemical characterization of microalgal biomass}

The approximate composition of microalgal biomass determined in this study (Table 2 ) is a confirmation of the high protein content reported by other authors in the Spirulina biomass (9) and the high lipid content of Nannochloropsis (26) biomass. These biomolecules are the main focus of the vast range of studies of microalgal biomass, from food formulation to biodiesel production.

Table 2. Mass fraction $(w)$ of components of microalgal biomass

\begin{tabular}{lcccccc}
\multirow{2}{*}{ Component } & \multicolumn{2}{c}{ Spirulina sp. } & & \multicolumn{3}{c}{ Nannochloropsis sp. } \\
\cline { 2 - 3 } \cline { 5 - 6 } Moisture & $w / \%$ & $\mathrm{CV} / \%$ & & $w / \%$ & $\mathrm{CV} / \%$ \\
Ash & 14.7 & 0.9 & & 8.5 & 1.8 \\
Lipids & 8.9 & 0.8 & & 9.7 & 7.8 \\
Proteins & 8.6 & 2.7 & & 39.1 & 1.6 \\
Fibre & 51.3 & 5.4 & & 27.0 & 0.2 \\
Carbohydrates & 1.6 & 9.2 & & 0.6 & 7.2 \\
\hline
\end{tabular}

$\mathrm{CV}=$ coefficient of variation, *estimated by difference

\section{Phenolic acids in microalgae}

The efficiency parameters of the chromatographic method employed to quantify the phenolic acids (Table 3 ) showed that it has adequate coefficients of determination, in agreement with International Union of Pure and Applied Chemistry (27) recommendations, of $R^{2}$ values equal to or higher than 0.9. Furthermore, the low phenolic acid quantification limit is important to ensure analysis reliability, especially when the objective is to determine trace components in biological matrices (28).
Table 3. Validation parameters of the chromatographic method used for determining phenolic acids

\begin{tabular}{lccccc} 
Phenolic acid & \multicolumn{2}{c}{$\gamma /(\mu \mathrm{g} / \mathrm{mL})$} & & \\
Gallic & 0.12 & $0.36-3.6$ & 0.998 & 5.4 & \\
\cline { 2 - 5 } Petection limit & Linearity & $\mathrm{R}^{2}$ & $k$ & $a$ \\
Protocatechuic & 0.27 & $0.81-8.1$ & 0.999 & 7.3 & \\
Chlorogenic & 0.41 & $1.23-12.3$ & 0.999 & 9.2 & 1.25 \\
Hydroxybenzoic & 0.32 & $0.96-9.6$ & 0.999 & 10.7 & 1.17 \\
Caffeic & 0.24 & $0.72-7.2$ & 0.999 & 12.6 & \\
Syringic & 0.25 & $0.75-7.5$ & 0.999 & 14.2 & \\
Vanillin & 0.18 & $0.54-5.4$ & 0.999 & 16.2 & \\
Coumaric & 0.19 & $0.57-5.7$ & 0.999 & 21.4 & 1.32 \\
Ferulic & 0.25 & $0.75-7.5$ & 0.999 & 26.6 & \\
\hline
\end{tabular}

$k=$ retention factor, $a=$ separation factor

The phenolic acid retention factors ranged from 5.4 to 26.6 , which is due to the long analysis time (16). In this study, we determined nine compounds in a 25-minute chromatographic run. Separation factors were above 1 and had appropriate elution sequence, with neither peak superposition nor peak enlargement despite the unusually large retention factor in some runs. The identification of phenolic acids found in microalgae (Table 4) showed that each phenolic fraction (methanolic, ethanolic and bound extracts) had different composition, as it was expected (2). The chromatograms of standards and phenolic extracts of microalgae in Fig. 2 show the efficiency of separation.

Table 4. Composition of phenolic acids in alcoholic phenolic extracts of Spirulina sp. and Nannochloropsis sp.

\begin{tabular}{|c|c|c|c|c|c|c|c|}
\hline \multirow{3}{*}{ Microalga } & \multirow{3}{*}{ Phenolic acid } & \multicolumn{6}{|c|}{ Phenolic extract fraction } \\
\hline & & \multicolumn{2}{|c|}{ Soluble in methanol } & \multicolumn{2}{|c|}{ Soluble in ethanol } & \multicolumn{2}{|c|}{ Bound } \\
\hline & & $w /(\mu \mathrm{g} / \mathrm{g})$ & $\mathrm{CV} / \%$ & $w /(\mu \mathrm{g} / \mathrm{g})$ & $\mathrm{CV} / \%$ & $w /(\mu \mathrm{g} / \mathrm{g})$ & CV/\% \\
\hline \multirow{7}{*}{ Spirulina sp. } & Gallic & 1.7 & 2.8 & - & - & - & - \\
\hline & Protocatechuic & 16.3 & 0.7 & - & - & - & - \\
\hline & Chlorogenic & 585.2 & 2.4 & 648.1 & 0.8 & 4.6 & 0.6 \\
\hline & Hydroxybenzoic & 24.6 & 3.2 & - & - & 11.8 & 8.1 \\
\hline & Syringic & - & - & - & - & 4.3 & 1.8 \\
\hline & Vanillin & - & - & 33.7 & 2.8 & 3.0 & 0.7 \\
\hline & Total & 627.8 & 2.3 & 681.9 & 1.8 & 23.6 & 2.8 \\
\hline \multirow{10}{*}{ Nannochloropsis sp. } & Gallic & 86.6 & 3.5 & - & - & - & - \\
\hline & Protocatechuic & 27.0 & 2.3 & 11.8 & 4.0 & - & - \\
\hline & Chlorogenic & 489.5 & 2.8 & 776.7 & 2.7 & 7.2 & 2.1 \\
\hline & Hydroxybenzoic & 26.8 & 1.4 & 21.2 & 7.8 & 21.6 & 3.9 \\
\hline & Caffeic & - & - & 64.9 & 7.1 & 8.2 & 3.7 \\
\hline & Syringic & 7.6 & 4.6 & 10.1 & 2.8 & 19.1 & 4.0 \\
\hline & Vanillin & 3.4 & 2.7 & 5.3 & 1.2 & 8.2 & 0.4 \\
\hline & Coumaric & - & - & - & - & 2.0 & 0.8 \\
\hline & Ferulic & 0.3 & 3.4 & - & - & - & - \\
\hline & Total & 641.2 & 3.0 & 890.0 & 4.3 & 66.3 & 2.5 \\
\hline
\end{tabular}

$\mathrm{CV}=$ coefficient of variation 
a)

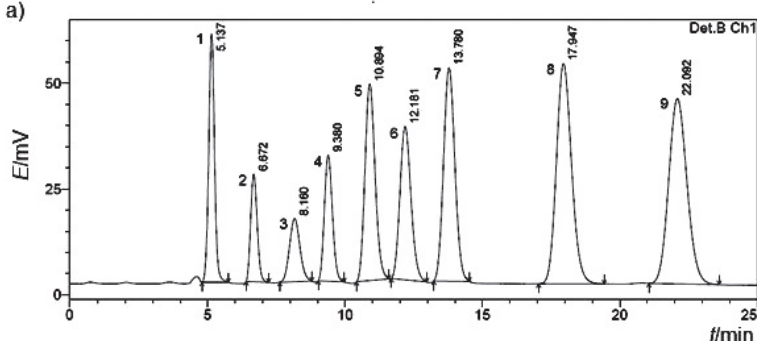

b)

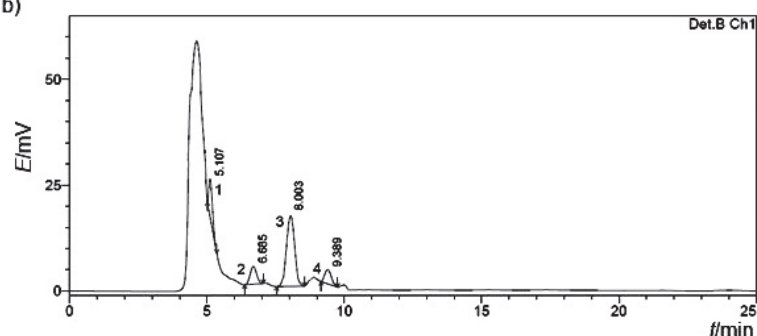

c)

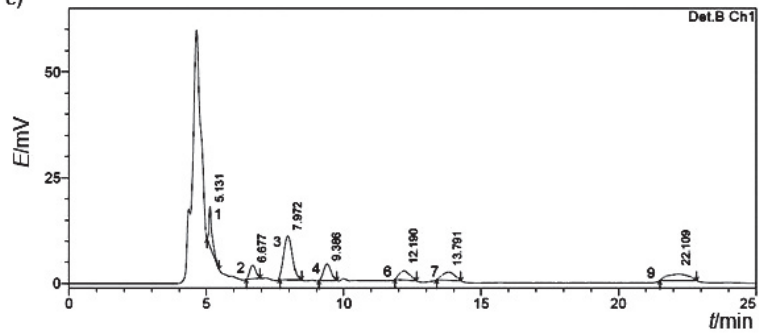

Fig. 2. Chromatogram of phenolic acids soluble in methanol: a) synthetic standards, b) Spirulina sp., c) Nannochloropsis sp. 1=gallic, 2=protocatechuic, 3=chlorogenic, 4=4-hydroxybenzoic, 5=caffeic, $6=$ syringic, $7=$ vanillin, $8=4$-coumaric and $9=$ ferulic acids

The profile of phenolic acids identified in the Spirulina biomass extracts was similar to the one reported by other authors who also found gallic, salicylic, trans-cinnamic and chlorogenic acids $(4,29)$. However, identification studies of Nannochloropsis biomass phenolic compounds that specifically mention distribution of phenols are sparse $(30,31)$.

Phenolic compounds are a large chemical family associated with defense mechanism against endogenous and exogenous factors, such as oxidative process, light, temperature and pathogen invasion. They have been found in photosynthetic microalgae $(4,29)$, however, their determination in microalgae is not frequent. The study of cells that produce these compounds is even more important than the phenolic compounds themselves. The determination of the profile of phenolic compounds in the cells can identify phenolic sources for application as natural preservatives in the food industry, therefore, they were the target of our experiment.

\section{Antioxidant activity of the microalgal extracts}

The ability of phenolic acids to donate hydrogen to the free radical that is formed in the cell determines their antioxidant properties. There are two groups of phenolic acids: derivates of benzoic and cinamic acids, whose chemical structures, especially their hydroxilated forms, determine their potential to protect against oxidants (2). They act by inhibiting the release and propagation of free radicals in some reactions and oxidative and hydrolytic enzymes. Therefore, to evaluate the antioxidant properties of phenolic compounds, it is recommendable to carry out methods that could reflect the antioxidation mechanism.

The main phenolic compound in aqueous extracts from microalgae found in this study was chlorogenic acid, whose antioxidant activity and capacity of inhibiting mutagenicity promoted by chemical compounds has already been shown (32).

Different procedures determined the antioxidant activity of the extracts to estimate their minimal concentration for the protective effect, stability and versatility of action mechanism. The determined radical ABTS inhibition showed the ability of the extracts to hinder the production of free radicals and allowed the estimation of the minimal dose-effect. DPPH is a stable radical with low deterioration and reactivity rates towards most compounds found in a biological system and may serve as indicator of the stability of antioxidant compounds. Only strong reducing agents are able to react with this type of radical stoichiometrically (20) and the determination allowed the evaluation of the stability of the phenolic acid inhibition. The determination of inhibition of peroxidase activity took into account the importance of knowing the prooxidant potential of the extracts, which can be evaluated by the inhibitory effect against the specific enzyme activity of peroxidase. This enzyme acts on reducing compounds of phenolic nature in the presence of hydrogen peroxide, thus yielding quinones depending on the oxidant potential of the substrate $(21,22)$. Within the cells, this enzyme participates in defense mechanisms but it may also lead to oxidative stress, however, it is expected that in microalgae the phenolic compounds are able to inhibit this process.

The phenolic extracts from microalgal biomass were significantly $(p<0.05)$ more efficient against ABTS radical (Table 5) than synthetic mixtures of phenolic acid, which suggests the ability to prevent free radical production. The higher efficiency of the crude phenolic extracts is promising and more advantageous than using purified phenolic acid compounds. The downstream processing of the crude extract may be difficult and expensive when considering mass production. Thus, using crude microalgal extracts can be more economically viable with more benefits than using a purified phenolic compound mixture.

Natural methanolic extracts from both microalgae had the highest inhibitory capacity against ABTS: 1.2 and $1.7 \% /(\mathrm{min} \cdot \mu \mathrm{g})$ from Spirulina sp. and Nannochloropsis sp., respectively. Values of $\mathrm{IC}_{50}$ obtained by the linear regression showed that the lowest concentration needed to capture $50 \%$ of the radical ABTS was achieved by Nannochloropsis sp. natural extract $\left(\mathrm{IC}_{50}=8.0\right.$ $\mu \mathrm{g} / \mathrm{mL}$ ), and its synthetic mixture was also the most efficient one $\left(\mathrm{IC}_{50}=14 \mu \mathrm{g} / \mathrm{mL}\right)$ among the artificial preparations. The antiradical potential of phenolic extracts refined with methanol is due to the synergy of different phenolic compounds. Therefore, purifying the phenolic acid from a natural phenolic extract, emulating the natural distribution of different kinds of phenolic compounds may not lead to optimal protection in food or pharmaceutical formulations (2). 
Table 5. Specific inhibitions of the radicals $\mathrm{ABTS}^{+}$and DPPH, and the enzyme activity of peroxidase and amylase in natural extracts and synthetic mixtures of microalgae

\begin{tabular}{|c|c|c|c|c|c|c|c|c|}
\hline \multirow[b]{2}{*}{ Parameter } & \multicolumn{2}{|l|}{ Spirulina sp. } & \multicolumn{2}{|c|}{ Synthetic Spirulina sp. } & \multicolumn{2}{|c|}{ Nannochloropsis sp. } & \multicolumn{2}{|c|}{ Synthetic Nannochloropsis sp. } \\
\hline & $\begin{array}{l}\text { Inhibition } \\
\% /(\min \cdot \mu \mathrm{g})\end{array}$ & $\mathrm{CV} / \%$ & $\begin{array}{l}\text { Inhibition } \\
\% /(\min \cdot \mu \mathrm{g})\end{array}$ & $\mathrm{CV} / \%$ & $\begin{array}{l}\text { Inhibition } \\
\% /(\text { min. } \mu \mathrm{g})\end{array}$ & $\mathrm{CV} / \%$ & $\begin{array}{l}\text { Inhibition } \\
\% /(\min \cdot \mu \mathrm{g})\end{array}$ & $\mathrm{CV} / \%$ \\
\hline$\gamma($ phenolics $) /(\mu \mathrm{g} / \mathrm{mL})$ & \multicolumn{8}{|c|}{ ABTS inhibition } \\
\hline 3.0 & $1.15^{\mathrm{b}}$ & 7.8 & $0.40^{\mathrm{d}}$ & 9.3 & $1.73^{\mathrm{a}}$ & 9.2 & $0.72^{\mathrm{c}}$ & 4.4 \\
\hline 5.0 & $0.96^{\mathrm{b}}$ & 2.7 & $0.40^{\mathrm{d}}$ & 7.3 & $1.33^{\mathrm{a}}$ & 10.1 & $0.68^{c}$ & 2.8 \\
\hline 10.0 & $0.93^{\mathrm{a}}$ & 7.7 & $0.35^{c}$ & 5.7 & $0.95^{\mathrm{a}}$ & 12.3 & $0.62^{\mathrm{b}}$ & 1.0 \\
\hline Linear regression & $y=5.1269 x+4.5282$ & - & $y=1.8983 x+1.941$ & - & $y=3.6239 x+21.367$ & - & $y=3.4845 x+2.7872$ & - \\
\hline $\mathrm{IC}_{50} /(\mu \mathrm{g} / \mathrm{mL})$ & 9.0 & - & 25 & - & 8.0 & - & 14 & - \\
\hline$t / \min$ & \multicolumn{8}{|c|}{ DPPH inhibition } \\
\hline 30 & $0.003^{c}$ & 20.7 & $0.014^{\mathrm{a}}$ & 2.2 & $0.026^{b}$ & 12.0 & $0.028^{\mathrm{a}}$ & 7.5 \\
\hline 60 & $0.006^{b}$ & 5.3 & $0.015^{\mathrm{a}}$ & 1.9 & $0.015^{\mathrm{a}}$ & 3.5 & $0.015^{\mathrm{a}}$ & 5.5 \\
\hline 90 & $0.007^{b}$ & 3.5 & $0.014^{\mathrm{ab}}$ & 1.1 & $0.011^{\mathrm{a}}$ & 10.1 & $0.010^{\mathrm{ab}}$ & 7.4 \\
\hline 120 & $0.007^{b}$ & 1.6 & $0.013^{\mathrm{ab}}$ & 1.0 & $0.010^{\mathrm{a}}$ & 11.7 & $0.008^{\mathrm{ab}}$ & 8.5 \\
\hline 150 & $0.007^{b}$ & 0.8 & $0.012^{\mathrm{ab}}$ & 0.8 & $0.009^{\mathrm{a}}$ & 12.9 & $0.007^{b}$ & 12.4 \\
\hline 180 & $0.007^{\mathrm{ab}}$ & 1.3 & $0.013^{\mathrm{ab}}$ & 0.0 & $0.008^{\mathrm{a}}$ & 15.8 & $0.006^{b}$ & 14.0 \\
\hline$t / \mathrm{min}$ & \multicolumn{8}{|c|}{ Peroxidase activity inhibition } \\
\hline 10 & $0.49^{b}$ & 1.5 & $0.49^{b}$ & 2.8 & $0.59^{\mathrm{a}}$ & 5.1 & $0.45^{b}$ & 9.7 \\
\hline 20 & $0.36^{\mathrm{a}}$ & 3.7 & $0.39^{\mathrm{a}}$ & 2.4 & $0.39^{\mathrm{a}}$ & 3.0 & $0.37^{\mathrm{a}}$ & 1.7 \\
\hline 30 & $0.27^{\mathrm{a}}$ & 0.6 & $0.28^{\mathrm{a}}$ & 0.6 & $0.28^{\mathrm{a}}$ & 2.0 & $0.28^{\mathrm{a}}$ & 0.3 \\
\hline & \multicolumn{8}{|c|}{ Amylase activity inhibition } \\
\hline & $0.075^{\mathrm{a}}$ & 0.7 & $0.012^{b}$ & 10.8 & $0.010^{\mathrm{b}}$ & 4.9 & - & - \\
\hline
\end{tabular}

For each method, average values followed by the same letters in the same row do not differ statistically according to Tukey's test ( $p<0.05$ ), $\mathrm{CV}=$ coefficient of variation

Table 5 shows the results of the assays of phenolic extracts from microalgae carried out during this study. The natural extract from Spirulina sp. showed the best properties during 180 min of monitoring the DPPH inhibitory activity. The natural extract and the synthetic mixtures of phenols from Nannochloropsis sp. showed a tendency to reduce the protecting effect of phenols, suggesting that they are more adequate to apply in situations where shorter protection intervals are necessary. The inhibitory effect of the phenolic extracts from Nannochloropsis sp. is beyond the capacity of the equivalent synthetic mixture; thus, it is a source of antioxidant compounds that may be explored to protect cells and products in situations where the inhibition of the oxidative process needs to occur much faster.

The compounds with antioxidant activity may act in different phases of the oxidative process (33). Considering our results of the ABTS and DPPH methods, the phenolic extracts from microalgae were able to inhibit the propagation phase. The reduction power stopped for short intervals, indicating that the extracts held to their free radical scavenging capacity, halting the chain reaction.

\section{Enzymatic inhibition effects of microalgal extracts}

It is worth mentioning that few studies have determined the inhibitory role of phenolic compounds in oxidative processes promoted by enzymatic action, however, it is very important in biological materials as part of early defense mechanism $(21,22)$. These are triggered by enzymes, mainly peroxidase, therefore its inhibition is an interesting sign of antioxidant action. The measurement of peroxidase activity in the presence of phenolic extracts enables to investigate the role of these compounds in cell defense mechanisms, choosing those of interest for use as preservatives in food industry. Table 5 shows that the best extract, when regarding this property, was the one from Nannochloropsis sp. It differed significantly $(p<0.05)$ from the others in the shortest study time.

The inhibitory activity of amylase from the extracts may constitute a natural defense mechanism of microalgae against fungal attacks and this may be interesting for protection against endogenous hydrolytic process. This potential was estimated by checking the inhibition capacities of each extract against fungal amylase. The natural Spirulina sp. extract had higher effect on the reduction of the activity of amylase, $0.08 \% /(\mathrm{min} \cdot \mu \mathrm{g})$, and differed significantly $(\mathrm{p}<0.05)$ from the other extracts. The synthetic mixture of this microalga had a reduction effect of $0.01 \% /(\mathrm{min} \cdot \mu \mathrm{g})$. Nannochloropsis sp. natural extract led to a $0.01 \% /(\mathrm{min} \cdot \mu \mathrm{g})$ reduction of this enzyme activity.

The inhibitory activity of amylase from microalgal phenolic compounds shows that their application against fungal contamination in the fields or for grain beneficiation may be viable. The production of compounds from microalgae with inhibitory effects against amylases has not been deeply investigated. Therefore, this study is pioneering and may contribute to inferring antifungal activity of phenolic extracts from microalgae, since they survive in environments where they compete with fungi (29). 


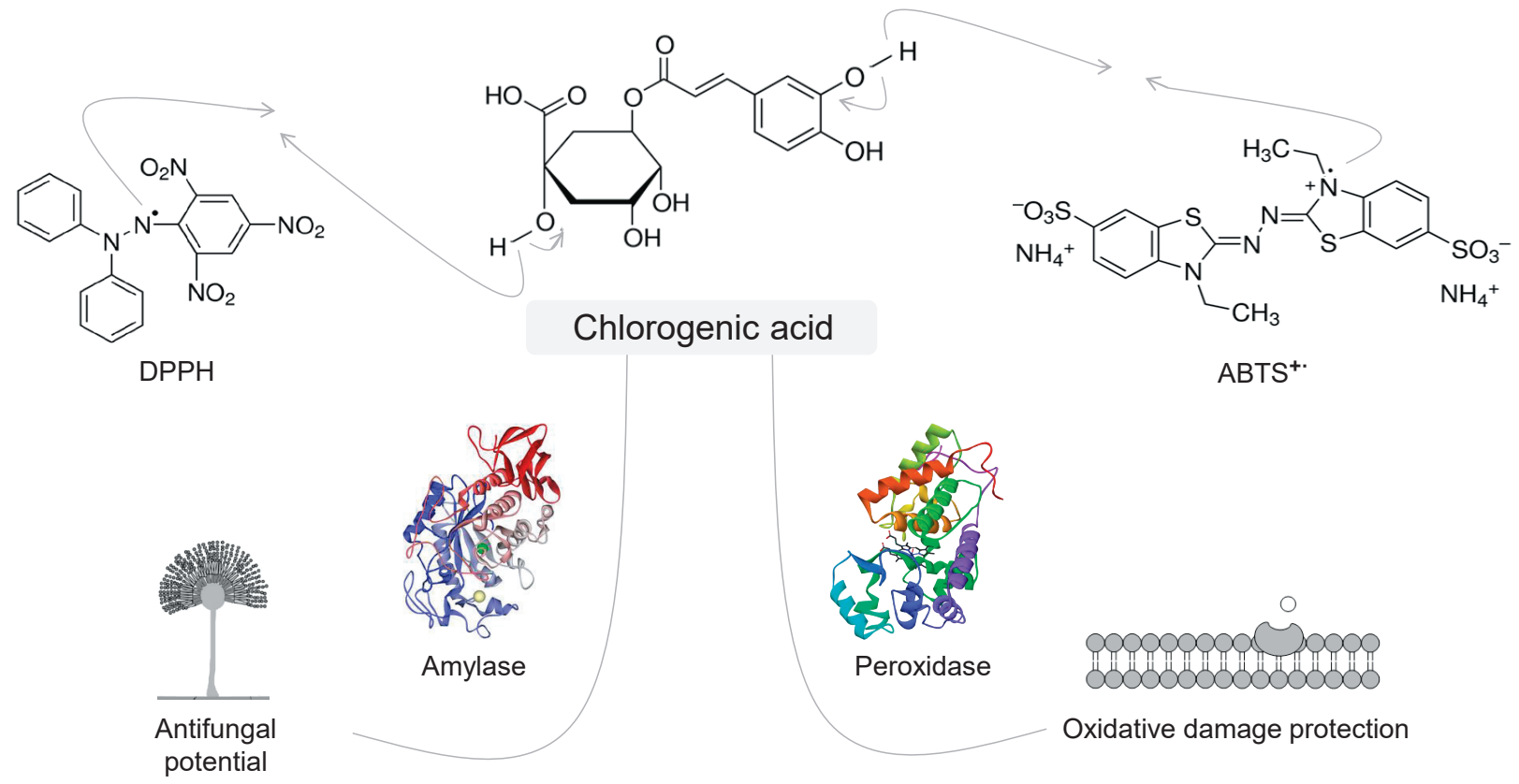

Fig. 3. Schematic representation of the role of chlorogenic acid as an antioxidant and an enzymatic inhibitor

Fig. 3 shows a schematic representation of the action mechanisms of phenolic acids, taking chlorogenic acid as an example, considering that this phenolic acid is present mostly in microalgae Nannochloropsis sp. and Spirulina sp.

\section{CONCLUSIONS}

Both microalgal extracts, Spirulina sp. and Nannochloropsis sp., had a substantial capacity to inhibit hydrolytic and oxidative degradation, with inhibition rates of 1.2 and $1.7 \%$ / $(\mathrm{min} \cdot \mu \mathrm{g})$, respectively. These high inhibition values facilitate the employment of the extracts in food preparation, since the concentration to achieve a $50 \%$ reduction of oxidative capacity of radicals is low, and thus, easy to produce on a large scale. Therefore, these extracts of phenolic compounds are an interesting alternative that may prevent oxidative and enzymatic degradation in the food production.

\section{ACKNOWLEDGEMENTS}

The authors would like to thank the Postgraduate Program in Food Science and Engineering (FURG) and CNPq - National Council for Scientific and Technological Development for the support of this study via the project 472633/2012. The Laboratory of Biochemical Engineering - FURG, especially Prof. Dr Jorge Alberto Vieira Costa for providing the microalgal biomass; CEME-SUL (Center of Southern Electron Microscopy - FURG) and LACOM (Laboratory of Analysis of Organic Compounds and Metals - FURG), especially Dr Sergiane Caldas for conducted analyses.

\section{REFERENCES}

1. Borges L, Morón-Villarreyes JA, D'Oca MGM, Abreu PC. Effects of flocculants on lipid extraction and fatty acid composition of the microalgae Nannochloropsis oculata and Thalassiosira weissflogii. Biomass Bioenergy. 2011; 35(10):4449-54.

https://doi.org/10.1016/j.biombioe.2011.09.003

2. Quideau S, Deffieux D, Douat-Casassus C, Pouységu L. Plant polyphenols: Chemical properties, biological activities, and synthesis. Angew Chem Int Ed Engl. 2011;50(3): 586-621.

https://doi.org/10.1002/anie.201000044

3. Lemos Mendes GR, Leal Alves C, Lopes Cavalheiro P, Bretanha CC, Arnhold Pagnussatt F, Badiale-Furlong E. a-Amylase inhibitors from wheat against development and toxigenic potential of Fusarium verticillioides. Cereal Chem. 2015;92(6):611-6. https://doi.org/10.1094/CCHEM-11-14-0227-R

4. Arnhold Pagnussatt F, Medeiros Del Ponte E, Garda-Buffon J, Badiale-Furlong E. Inhibition of Fusarium graminearum growth and mycotoxin production by phenolic extract from Spirulina sp. Pest Biochem Physiol. 2014;108:21-6. https://doi.org/10.1016/j.pestbp.2013.11.002

5. Jia Z, Dumont MJ, Orsat V. Encapsulation of phenolic compounds present in plants using protein matrices. Food Biosci. 2016;15:87-104.

https://doi.org/10.1016/j.fbio.2016.05.007 
6. Heidtmann-Bemvenuti R, Moser Tralamazza S, Ferreira CFJ, Corrêa B, Badiale-Furlong E. Effect of natural compounds on Fusarium graminearum complex. J Sci Food Agric. 2016;96(12):3998-4008. https://doi.org/10.1002/jsfa.7591

7. Ravn H, Andary C, Kovács G, Mølgaard P. Caffeic acid esters as in vitro inhibitors of plant pathogenic bacteria and fungi. Biochem Syst Ecol. 1989;17(3):174-84. https://doi.org/10.1016/0305-1978(89)90076-8

8. Custódio L, Justo T, Silvestre L, Barradas A, Duarte CV, Pereira $\mathrm{H}$, et al. Microalgae of different plyla display antioxidant, metal chelating and acetylcholinesterase inhibitory activities. Food Chem. 2012;131(1):134-40. https://doi.org/10.1016/j.foodchem.2011.08.047

9. Morais MG, Radmann EM, Andrade MR, Teixeira GG, Brusch LRF, Costa JAV. Pilot scale semicontinuous production of Spirulina biomass in southern Brazil. Aquaculture. 2009;294(1-2):60-4. https://doi.org/10.1016/j.aquaculture.2009.05.009

10. AOAC Official Method 930.04. Moisture in plants. In: Horwitz W, Latimer GW, editors. AOAC International Methods. Gaithersburg, MD, USA: AOAC International; 2005.

11. AOAC Official Method 954.02. Fat (crude) or ether extract in pet food. In: Horwitz W, Latimer GW, editors. AOAC International Methods. Gaithersburg, MD, USA: AOAC International; 2005.

12. AOAC Official Method 930.05. Ash of plants. In: Horwitz W, Latimer GW, editors. AOAC International Methods. Gaithersburg, MD, USA: AOAC International; 2005.

13. AOAC Official Method 977.02. Nitrogen (total) (crude protein) in plants. In: Horwitz W, Latimer GW, editors. AOAC International Methods. Gaithersburg, MD, USA: AOAC International; 2005.

14. AOAC Official Method 978.10. Fiber (crude) in animal feed and pet food. In: Horwitz W, Latimer GW, editors. AOAC International Methods. Gaithersburg, MD, USA: AOAC International; 2005.

15. Scaglioni PT, de Souza TD, Schmidt CG, Badiale-Furlong E. Availability of free and bound phenolic compounds in rice after hydrothermal treatment. J Cereal Sci. 2014; 60(3):526-32.

\section{https://doi.org/10.1016/j.jcs.2014.08.005}

16. Analytical procedures and methods validation for drugs and biologics. Guidance for industry. Silver Spring, MD, USA: United States Food and Drug Administration (USFDA); 2000.

17. MassLynx, v. 4.1, Waters Corp. Milford, MA, USA; 2005. Available from: http://www.waters.com/.

18. Singh A, Bajpai V, Kumar S, Kumar B, Srivastava M, Rameshkumar KB. Comparative profiling of phenolic compounds from different plant parts of six Terminalia species by liquid chromatography-tandem mass spectrometry with chemometric analysis. Ind Crops Prod. 2016;87:236-46.

https://doi.org/10.1016/j.indcrop.2016.04.048

19. Bhoyar MS, Mishra GP, Naik PK, Srivastava RB. Estimation of antioxidant activity and total phenolics among natural populations of Caper (Capparis spinosa) leaves collected from cold arid desert of trans-Himalayas. Aust J Crop Sci. 2011;5(7):912-9.

20. Fadda A, Serra M, Molinu MG, Azara E, Barberis A, Sanna $D$. Reaction time and DPPH concentration influence antioxidant activity and kinetic parameters of bioactive molecules and plant extracts in the reaction with the DPPH radical. J Food Compost Anal. 2014;35(2):112-19.

https://doi.org/10.1016/j.jfca.2014.06.006

21. Cardinali A, Tursi N, Ligorio A, Giuffrida MG, Napolitano L, Caliandro $\mathrm{R}$, et al. Purification, biochemical characterization and cloning of a new cationic peroxidase isoenzyme from artichoke. Plant Physiol Biochem. 2011;49(4):395-403. https://doi.org/10.1016/j.plaphy.2011.01.028

22. Devaiah SP, Shetty HS. Purification of an infection-related acidic peroxidase from pearl millet seedlings. Pestic Biochem Physiol. 2009;94(2-3):119-26.

https://doi.org/10.1016/j.pestbp.2009.04.010

23. Lowry OH, Rosenbrough MJ, Farr AL, Randall RJ. Protein measurement with the Folin phenol reagent. J Biol Chem. 1952;193(1):265-75.

24. Arnhold Pagnussatt F, Rivero Meza SL, Garda-Buffon J, Badiale-Furlong E. Procedure to determine enzyme inhibitors activity in cereal seeds. J Agric Sci. 2012;4:85-92. https://doi.org/10.5539/jas.v4n12p85

25. STATISTICA, v. 12, StatSoft Inc, Tulsa, OK, USA; 2013. Available from: http://www.statsoft.com.

26. Var Vooren G, Le Grand F, Legrand J, Cuiné S, Peltier G, Pruvost J. Investigation of fatty acids accumulation in Nannochloropsis oculata for biodiesel application. Bioresour Technol. 2012;124:421-32.

https://doi.org/10.1016/j.biortech.2012.08.009

27. International Union of Pure and Applied Chemistry (IUPAC). Guidelines for calibration in analytical chemistry, Part 1. Fundamentals and single component calibration. Pure Appl Chem. 1998;70(4):993-1014.

28. Guidance document on pesticide residue analytical methods, SANCO/825/00 rev. 8.1. European Commission, Directorate General Health and Consumer Protection, Brussels, Belgium; 2010.

29. Souza MM, Prieto L, Ribeiro AC, Souza TD, Badiale-Furlong E. Assesment of the antifungal activity of Spirulina platensis phenolic extract against Aspergillus flavus. Ciênc Agrotec. 2011;35(6):1050-8.

https://doi.org/10.1590/S1413-70542011000600003

30. Ahmed F, Fanning K, Netzel M, Turner W, Li Y, Schenk PM. Profiling of carotenoids and antioxidant capacity of 
microalgae from subtropical coastal and brackish waters. Food Chem. 2014;165:300-6.

https://doi.org/10.1016/j.foodchem.2014.05.107

31. Maadane A, Merghoub N, Ainane T, El Arroussi H, Benhima $\mathrm{R}$, Amzazi S, et al. Antioxidant activity of some Moroccan marine microalgae: Pufa profiles, carotenoids and phenolic content. J Biotechnol. 2015;215:13-9.

https://doi.org/10.1016/j.jbiotec.2015.06.400
32. Rakshit S, Mandal L, Pal BC, Bagchi J, Biswas N, Chaudhuri J, et al. Involvement of ROS in chlorogenic acid-induced apoptosis of Bcr-Abl+CML cells. Biochem Pharmacol. 2010; 80(11):1662-75.

https://doi.org/10.1016/j.bcp.2010.08.013

33. Damodaran S, Parkin KL, Fennema OR. Fennema's food chemistry. Porto Alegre, Brazil: Artmed; 2010 (in Portuguese). 